\title{
Pengaruh Disiplin Dan Aktivitas Belajar Terhadap Hasil Belajar Mahasiswa Pendidikan Guru Madrasah Ibtidaiyah FAI UM Sumatera Barat
}

\author{
Dini Susanti ${ }^{1}$ \\ UM Sumatera Barat \\ dinisusanti35@gmail.com \\ Reni Nastuti \\ STKIP YDB Lubuk Alung \\ reni.nastuti@gmail.com
}

\begin{abstract}
This research is an expost facto research, this research was conducted after seeing the phenomena that had occurred to the students of PGMI FAI Um West Sumatra after making observations. The results of the observations found that there were students who were not disciplined in learning and were still less active in participating in lessons. Researchers want to know whether there is an influence of discipline and learning activities on student learning outcomes. This study aims to determine: (1) the effect of discipline on student learning outcomes of PGMI students, (2) the effect of learning activities on student learning outcomes of PGMI students, (3) the effect of discipline and learning activities together on student learning outcomes of PGMI students. The research instrument to examine discipline and activity on learning outcomes is a questionnaire technique in which alternative answers have been provided. Then the population in this study were all PGMI students for the 2020/2021 academic year. This study uses quantitative methods, the analysis used is descriptive statistics and inferential statistics using computerization using the SPSS (Statistical Product and Service Solution) program. So that the results of this study are: (1) Partially only discipline has a positive effect on learning outcomes, while for the variable (2) Learning activities have no effect on student learning outcomes, (3) Together, discipline and learning activities affect learning outcomes study.
\end{abstract}

Keywords: Discipline, Learning Activities, Student Learning Outcomes

\begin{abstract}
Abstrak
Penelitian ini adalah penelitian expost facto, penelitian ini dilakukan setelah melihat fenomena-fenomena yang telah terjadi pada mahasiswa PGMI FAI Um Sumatera Barat setelah melakukan observasi. Hasil observasi menemukan bahwa terdapat mahasiswa yang belum disiplin dalam belajar dan masih kurang aktif dalam mengikuti pelajaran. Peneliti ingin mengetahui apakah terdapat pengaruh disiplin dan aktivitas belajar ini terhadap hasil belajar mahasiswa. Penelitian ini bertujuan untuk mengetahui: (1) Pengaruh disiplin terhadap hasil belajar mahasiswa PGMI, (2) pengaruh aktivitas belajar terhadap hasil belajar mahasiswa PGMI, (3) pengaruh disiplin dan aktivitas belajar secara bersama-sama terhadap
\end{abstract}


hasil belajar mahasiswa PGMI. Instrumen penelitian untuk meneliti kedisiplinan dan aktivitas terhadap hasil belajar adalah teknik angket yang dimana telah disediakan alternatifalternatif jawaban yang telah disediakan. Kemudian populasi dalam penelitian ini adalah seluruh mahasiswa PGMI tahun ajaran 2020/2021. Penelitian ini menggunakan metode kuantitatif, analisis yang digunakan adalah statistik deskriptif dan statistik inferensial dengan menggunakan komputerisasi dengan memanfaatkan program SPSS (Statistical Product and Service Solution). Sehingga diperoleh hasil penelitian ini yaitu: (1) Secara parsial hanya disiplin yang berpengaruh positif terhadap hasil belajar, sedangkan untuk variabel (2) Aktivitas belajar tidak berpengaruh terhadap hasil belajar mahasiswa, (3) Secara bersama-sama disiplin dan aktivitas belajar berpengaruh terhadap hasil belajar.

Kata Kunci: Disiplin, Aktivitas Belajar, Hasil Belajar Siswa 


\section{PENDAHULUAN}

Pendidikan merupakan kebutuhan pada diri setiap manusia yang dimulai sejak lahir hingga meninggal dunia, bahkan manusia tidak akan pernah dapat menjadi manusia yang berkepribadian baik tanpa melalui pendidikan. Pendidikan sama dengan hidup, yaitu segala situasi dalam hidup yang mempengaruhi pertumbuhan seseorang. Pendidikan bersifat universal yang berarti dapat diakses dan dimiliki oleh semua anak bangsa tanpa terkecuali. Di negara Indonesia, pendidikan merupakan hak bagi setiap warga negara. Hal ini diatur dalam batang tubuh Undang-undang Dasar Negara Republik Indonesia tahun 1945 Pasal 31 Ayat 1 yang berbunyi "Setiap warga negara berhak mendapatkan pendidikan" (Herawati, 2016).

Disiplin belajar merupakan salah satu sikap ketaatan yang harus dimiliki mahasiswa agar memiliki cara belajar yang baik. Disiplin belajar dipandang sebagai faktor yang mempengaruhi hasil belajar mahasiswa. Sikap dan perilaku disiplin tidak terbentuk dengan sendirinya dan dalam waktu yang singkat, namun melalui proses yang cukup panjang. Disiplin akan terwujud melalui pembinaan yang dilakukan sejak dini mulai dari lingkungan keluarga dan berlanjut dalam pendidikan di Universitas. Keluarga dan sekolah menjadi tempat penting bagi perkembangan disiplin belajar mahasiswa (Darsiah, 2020).

Belajar dengan disiplin terarah dapat menghindarkan diri dari rasa malas dan menumbuhkan kegairahan mahasiswa dalam belajar. Disiplin belajar dapat dilaksanakan di sekolah/universitas maupun di rumah. Mahasiswa melaksanakan disiplin belajar di universitas dengan menaati tata tertib sekolah, aktif dalam kegiatan pembelajaran, mengerjakan tugas yang diberikan oleh dosen, aktif masuk dalam perkuliahan dan lain-lain. Kalau disiplin belajar di rumah, mahasiswa senantiasa belajar secara teratur dan tanpa paksaan orang lain. Namun melihat kenyataannya di lapangan, nampaknya mahasiswa belum sepenuhnya memahami pentingnya disiplin belajar. Tidak jarang siswa menganggap belajar sebagai hal yang membosankan terutama belajar di rumah. Padahal, disiplin merupakan kunci kesuksesan seseorang.

Suatu proses belajar dikatakan baik, bila proses tersebut dapat membangkitkan aktivitas belajar yang efektif. Seorang anak itu berfikir sepanjang ia berbuat. Tanpa perbuatan berarti anak itu tidak berfikir. Oleh karena itu, agar anak berfikir sendiri, maka aktivitas belajar perlu dipacu agar mendukung proses belajarnya (Septiana \& Mahmud, 2019).

Ketika sebuah disiplin telah tertanam 
kuat dalam diri mahasiswa, maka mereka tidak akan merasa terpaksa untuk melakukan segala sesuatu yang berhubungan dengan kehidupannya terutama belajar sehingga akan memperoleh hasil yang memuaskan. Oleh karena itu, disiplin belajar sangat diperlukan oleh setiap mahasiswa untuk mencapai kesuksesan belajarnya.

Kegiatan atau aktivitas inilah yang juga terjadi dan didapatkan di PGMI, aktivitas inilah yang nantinya menentukan tingkat berhasil atau tidaknya kegiatan belajar mahasiswa. Selain itu dibutuhkan pula disiplin dalam pengelolaan pengajaran seperti halnya, disiplin belajar, disiplin waktu, disiplin mengerjakan tugas dan disiplin dalam mentaati tata tertib universitas. Oleh sebab itu disiplin harus ditanamkan sejak dini pada setiap diri manusia, karena disiplin sebagai latihan yang bertujuan mengembangkan watak agar dapat mengendalikan diri, berperilaku tertib, efektif dan efisien dalam belajar.

Disiplin secara rutin memang sulit dilaksanakan, maka perlu pembinaan dan latihan yang rutin untuk membentuk sikap dan kebiasaan belajar yang baik. Maka dari itu disiplin sangat diperlukan begitupun dengan aktivitas belajar. Karena dengan memenuhi keduanya ini maka akan memperoleh hasil belajar yang baik (Ekawati, 2016).
Bedasarkan informasi yang peneliti peroleh melalui wawancara dengan beberapa dosen yang mengajar di PGMI FAI UM Sumatera Barat pada tanggal 12 Februari 2021, banyak faktor yang mempengaruhi hasil belajar siswa antara lain 1) motivasi belajar, 2) pengaruh teman sebaya, 3) fasilitas belajar, 4) ketidakdisiplinan belajar, 5) metode yang digunakan dosen kurang bervariasi, 6) aktivitas belajar dan lain-lain. Disiplin belajar dan aktivitas belajar merupakan salah satu faktor yang cukup dominan bagi masiswa untuk mencapai hasil belajar yang memuaskan.

Berdasarkan observasi yang sudah peneliti lakukan, ketidakdisiplinan siswa diantaranya 1) melalaikan tugas yang diberikan dosen, 2) melanggar tata tertib, 3) mengerjakan tugas di kempus, 4) terlambat masuk kelas, 5) tidak memakai atribut lengkap, 6) tidak membawa alat tulis yang lengkap, 7) tidak semua mahasiswa memperhatikan penjelasan dosen sehingga ketika diberi tugas tidak bisa mengerjakan, 8) ada mahasiswa yang mencontek saat ulangan tengah semester, 9) mengganggu teman lain saat mengerjakan tugas/diskusi. perilaku mahasiswa yang demikian mencerminkan bahwa dalam diri anak tersebut belum tertanam disiplin belajar yang baik. Salah satu hal yang mendasari disiplin belajar mahasiswa adalah 
timbulnya kesadaran mahasiswa untuk mau melaksanakan dan menyelesaikan tugastugas belajarnya dengan baik, sesuai dengan tanggung jawabnya sebagai mahasiswa.

Faktor selanjutnya yang diduga turut mempengaruhi hasil belajar mahasiswa PGMI adalah aktivitas belajar. Faktor yang mempengaruhi hasil belajar mahasiswa antara lain belum maksimalnya adalah 1) aktivitas belajar mahasiswa, 2) banyak mahasiswa yang tidak antusias menanyakan hal- hal yang kurang mereka pahami ataupun menjawab pertanyaan yang diajukan oleh dosennya, 3) bahkan ketika dosen sedang menjelaskan materi dan memberikan pertanyaan mahasiswa masih melakukan aktivitas lain di dalam kelas seperti melamun, mengantuk, mengobrol dengan teman sehingga menimbulkan keributan yang akhirnya mengganggu konsentrasi mahasiswa lain sehingga tercipta suasana belajar yang tidak kondusif.

Beberapa faktor tersebut diduga menjadi penyebab masih ada hasil belajar mahasiswa yang kurang memuaskan padahal, hasil belajar merupakan tolak ukur kemampuan mahasiswa setelah melakukan kegiatan belajar selama periode waktu tertentu.

Peneliti bermaksud mengadakan penelitian di PGMI FAI UM Sumatera Barat dikarenakan masih terdapatnya hasil belajar mahasiswa yang kurang memuaskan. Berdasarkan masalah tentang pentingnya disiplin dan aktivitas belajar tersebut maka peneliti tertarik untuk membuktikan apakah ada pengaruh disiplin dan aktivitas belajar terhadap hasil belajar mahasiswa.

\section{METODE PENELITIAN}

\section{Rancangan Penelitian}

Dalam penelitian ini peneliti memilih penelitian yang berbentuk kuantitatif. Pendekatan kuantitatif dapat dilakukan untuk menguji teori tertentu dengan cara meneliti hubungan antar variabel. Metode penelitian kuantitatif dapat diartikan sebagai metode penelitian yang berlandaskan pada filsafat positivisme, digunakan untuk meneliti pada populasi atau sampel tertentu, teknik pengumpulan sampel umumnya dilakukan secara random, pengumpulan data menggunakan instrumen penelitian analisis data bersifat kuantitatif/statistik dengan tujuan untuk menguji hipotesis yang telah ditetapkan (Sugiyono, 2009).

Metode ini dipilih karena penelitian ini bertujuan untuk menemukan ada tidaknya pengaruh antara disiplin dan aktivitas belajar terhadap hasil belajar mahasiswa PGMI.

\section{Populasi dan Sampel}

Populasi atau population mempunyai 
arti yang bervariasi. Menurut Ary, dkk dalam (Sukardi, 2003:53) 'population is all members of well defined class of people, events or objects'. Sedangkan menurut (Sukardi, 2003) "Populasi adalalah semua anggota kelompok manusia, binatang, peristiwa atau benda yang tinggal bersama dalam satu tempat dan secara terencana menjadi target kesimpulan dari hasil akhir suatu penelitian”. Jadi, populasi merupakan keseluruhan dari objek yang diteliti. Populasi dalam penelitian ini adalah seluruh mahasiswa PGMI pada semester genap yang berjumlah 60 orang yang dibagi menjadi 3 lokal.

Uji validitas data bertujuan untuk mengetahui sejauh mana validitas yang didapat dari penyebaran angket. "Hasil penelitian yang valid bila terdapat kesamaan antara data yang terkumpul dengan data sesungguhnya terjadi pada obyek yang diteliti" (Sugiyono, 2009). Validitas menggambarkan bahwa pertanyaan yang digunakan mampu mengungkapkan sesuatu yang akan diukur. Peneliti terlebih dahulu akan melakukan uji validitas menggunakan rumus product moment dengan bantuan menggunakan rumus product moment dengan bantuan microsoft excel.

Pada variabel $\left(\mathrm{X}_{1}\right)$ disiplin terdapat 15 item soal yang valid yaitu nomor 1, 5, 7, $10,12,13,14,15,16,17,18,19,20,21$,
23 dan 8 soal yang tidak valid yaitu nomor 2, 3, 4, 6, 8, 9, 11 dan 22. Sedangkan untuk variabel $\left(\mathrm{X}_{2}\right)$ aktivitas belajar siswa terdapat 8 soal yang valid yaitu pada nomor 26,28 , 29, 31, 39, 40, 43, 46 dan soal yang tidak valid berjumlah 16 yaitu nomor 24, 25, 27, $30,32,33,34,35,36,37,38,41,42,44$, 45 dan 47.

Setelah berkonsultasi dengan teman sebaya, tidak ada soal yang dibuang karena untuk pernyataan yang tidak valid diperbaiki kata-kata dan bahasanya sesuai dengan kemampuan dan keadaan mahasiswa PGMI.

\section{Uji Reliabilitas}

Uji reabilitas dimaksudkan untuk mengukur seberapa besar suatu pengukuran mengukur dengan stabil dan konsisten. Hasil penelitian yang reliabel, bila terdapat kesamaan data dalam waktu yang berbeda (Sugiyono, 2013). Instrument dipercaya jika jawaban dari responden atas pertanyaan adalah konsisten atau stabil dari waktu kewaktu. Untuk menentukan reabilitas peneliti menggunakan rumus alpha Cronbach dengan bantuan Microsoft excel.

Setelah melakukan uji coba angket kepada siswa kelas V MIN 1 Kota Padang kemudian dilakukan analisis maka terlihat hasil reliabel butir. Untuk disiplin $r$ tabel sebesar 0,413 dan Alfpha Cronbach sebesar 0,78435 , kemudian untuk aktivitas belajar $\mathrm{r}$ tabel sebesar 0,404 dan Alfpha Cronbach 
sebesar 0,69262, jadi dapat disimpulkan bahwa keseluruhan butir untuk disiplin dan aktivitas belajar tersebut reliabel.

\section{Teknik Analisis Data}

Menurut "kegiatan yang dilakukan dalam analisis data adalah pengelompokkan data berdasarkan variabel dan jenis responden, mentabulasi data berdasarkan menyajikan data tiap variable yang diteliti, menghitung agar rumusan masalah terjawab, dan menghitung agar rumusan masalah terjawab, dan menghitung untuk uji hipotesis".

Berdasarkan rumusan masalah di atas, maka untuk menganalisis data tersebut dilakukan dengan analisis statistik deskriftif dan inferensial. Untuk statistik deskriptif menggunakan rumus :

$$
\begin{aligned}
& \mathrm{P}=\mathrm{x} 100 \\
& \text { Keterangan : } \\
& \mathrm{P} \quad=\text { Persentase } \\
& \mathrm{f} \quad=\text { Frekuensi } \\
& \mathrm{n} \quad=\text { Jumlah responden }
\end{aligned}
$$

Untuk uji hipotesis digunakan statistik inferensial regresi linier dengan persamaan struktur dapat digambarkan:

$$
\mathbf{Y}=\quad \mathrm{YX}_{1} \mathbf{X}_{1}+\mathrm{YX}_{2} \mathbf{X}_{2}+\mathrm{Y}+
$$
1

dengan diagram jalur sebagai berikut :

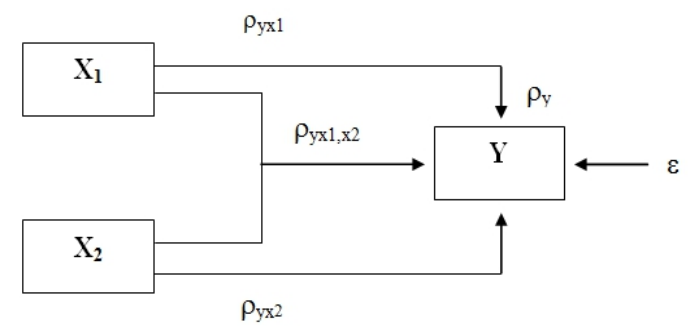

\section{HASIL PENELITIAN}

1. ambaran Umum Tingkat Disiplin PGMI

Berdasarkan data yang tingkat disiplin mahasiswa PGMI, dapat disimpulkan bahwa siswa yang memiliki tingkat disiplin dengan klasifikasi sangat disiplin berjumlah 20 orang $(23,53 \%)$, klasifikasi disiplin berjumlah 27 orang (31,76\%), klasifikasi kurang disiplin 35 orang (41,18\%), dan klasifikasi tidak disiplin 3 orang $(3,53 \%)$. Bila dilakukan penjumlahan skor dengan menggunakan mean $=75,36$. Harga ini jika dikonsultasikan dengan klasifikasi disiplin dapat dikatakan "Disiplin" karena terletak pada interval 73-82.

\section{Gambaran Umum Aktivitas Belajar Mahasiswa PGMI}

Untuk mengetahui gambaran aktivitas belajar mahasiswa PGMI dilakukan dengan cara menyebarkan kuesioner, sebagaimana yang dilakukan untuk mengetahui gambaran tingkat disiplin siswa.

Dari data yang didapatkan dari kuesioner tersebut, maka dapat diambil kesimpulan bahwa mahasiswa yang memiliki aktivitas belajar sangat aktif berjumlah 7 orang $(8,23 \%)$, klasifikasi aktif berjumlah 22 orang $(25,89 \%)$, klasifikasi kurang aktif berjumlah 37 orang (43,53\%) dan klasifikasi tidak aktif berjumlah 19 orang (22,35\%). Bila dilakukan 
penjumlahan skor dengan menggunakan mean=73,18. Harga ini jika dikonsultasikan dengan klasifikasi aktivitas belajar siswa dapat dikatakan "Kurang Aktif" karena berkisar pada interval 67-76. Dengan demikian dapat disimpulkan, rata-rata gambaran aktivitas belajar mahasiswa tergolong "Kurang Aktif".

\section{Gambaran Umum Hasil Belajar Mahasiswa PGMI}

Untuk mengetahui gambaran umum hasil belajar mahasiswa PGMI diperoleh dari hasil nilai ulangan tengah semester. Berdasarkan hasil kesioner, terlihat hasil belajar siswa sangat bagus berjumlah 10 orang (11,77\%), klasifikasi bagus berjumlah 15 orang $(17,65 \%)$, klasifikasi sedang berjumlah 19 orang (22,35\%), klasifikasi sangat kurang bagus berjumlah 32 orang $(37,65 \%)$ dan klasifikasi tidak bagus berjumlah 9 orang $(10,58 \%)$. Bila dilakukan penjumlahan dengan menggunkan mean $=87,37$. Nilai ini jika dikonsultasikan dengan klasifikasi hasil belajar dapat dikatakan "Sedang" karena terletak pada interval $86,6-89,5$.

Dengan demikian dapat disimpulkan, rata-rata gambaran hasil belajar mahasiswa tergolong "Sedang”.

4. Hubungan Disiplin dan Aktivitas Belajar terhadap Hasil Belajar Mahasiswa PGMI

Segala sesuatu yang berpengaruh pasti memiliki hubungan, tapi segala sesuatu yang memiliki hubungan belum tentu memiliki pengaruh dan pengaruh adalah lanjutan dari hubungan. Jadi, sebelum membahas pengaruh disiplin dan aktivitas belajar terhadap hasil belajar, kita lihat dulu apakah terdapat hubungan antara disiplin dan aktivitas belajar dengan hasil belajar.

a. $\mathrm{H}_{0}$ : Tidak terdapat Hubungan Disiplin dengan Hasil Belajar Mahasiswa PGMI

Setelah dilakukan analisis data Correlations dengan bantuan SPSS 20. Dari hasil perhitungan dilihat dari segi hubungan dengan $\mathrm{N}$ 85. Jika uji hipotesa adalah sig alfha $<0,05$, maka Ha diterima dan $\mathrm{H}_{0}$ ditolak, jika sig alfha $>0,05$ maka $\mathrm{Ha}$ ditolak dan $\mathrm{H}_{0}$ diterima. Maka didapat hubungan disiplin dengan hasil belajar mahasiswa PGMI dilihat dari nilai sig alfha adalah $0,001<0,05$. Berdasarkan nilai sig alfha maka H0 ditolak dan Ha diterima, maka terdapat hubungan antara disiplin dengan hasil belajar mahasiswa PGMI.

b. Ho: Tidak terdapat Hubungan Aktivitas

Belajar dengan Hasil Belajar

Mahasiswa PGMI

Setelah dilakukan analisis data dengan bantuan SPSS 20, diperoleh nilai sig sebesar 0,136 berarti lebih besar dari sig alfha 0,05 , jadi $\mathrm{H}_{0}$ diteima dan Ha ditolak, maka dapat disimpulkan bahwa aktivitas tidak mempunyai hubungan dengan hasil 
belajar mahasiswa PGMI

c. $\mathrm{H}_{0}$ : Tidak terdapat Hubungan antara Disiplin dan Aktivitas Belajar dengan Hasil Belajar Mahasiswa PGMI.

Untuk mengetahui signifikannya hubungan disiplin dan aktivitas belajar terhadap hasil belajar mahasiswa dilihat dari hasil uji hipotesa Sig. F Change $<0,05$ maka Ha diterima dan $\mathrm{H}_{0}$ ditolak dan jika Sig. F Change $>0,05$ maka $\mathrm{H}_{0}$ diterima dan Ha ditolak. Setelah dilakukan analisis data dengan bantuan SPSS 20, diperoleh nilai Sig. F Change sebesar $0,005<0,05$, jadi secara bersama-sama disiplin dan aktivitas belajar mempunyai hubungan yang signifikan terhadap hasil belajar mahasiswa PGMI.

\section{Uji Asumsi}

Uji asumsi dilakukan sebelum melakukan uji hipotesis, adapun uji asumsi sebagai berikut:

a. Normalitas

Untuk mencari normalitas menggunakan Program SPSS 20 dengan N 85 One-Sample Kolmogorov-Smirnov Test dengan ketentuan

Nilai sig yang diperoleh lebih besar dari alfha 0,05 maka data yang diperoleh normal dan sebaliknya jika nilai sig lebih kecil dari alfha 0.05 berarti data yang diperoleh tidak normal. Nilai sig untuk disiplin adalah 0,314 > 0,05, nilai sig untuk aktivitas belajar adalah $0,650>0,05$ dan nilai sig untuk hasil belajar adalah 0,262 >0,05. Maka dapat disimpulkan data untuk disiplin, aktivitas belajar dan hasil belajar berdistribusi normal.

b. Homogenitas

Homogenitas data dicari menggunakan program SPSS 20 dengan N 85 Test Of Homogenety Of Variances. Jika nilai sig yang diperoleh lebih besar dari alfha 0,05 maka data yang diperoleh homogen dan sebaliknya jika nilai sig lebih kecil dari alfha 0,05 berarti data yang diperoleh tidak homogen.

Berdasarkan hasil pengujian diketahui bahwa nilai sig variabel disiplin $\left(\mathrm{X}_{1}\right)$ berdasarkan variabel disiplin terhadap hasil belajar (Y) yaitu 0,217, sedangkan nilai sig variabel aktivitas belajar $\left(\mathrm{X}_{2}\right)$ berdasarkan variabel aktivitas belajar siswa terhadap hasil belajar (Y) yaitu 0,825 . Maka dapat disimpulkan bahwa data disiplin dan aktivitas belajar siswa terhadap hasil belajar mempunyai varian yang sama atau homogen.

Dari uji asumsi normalitas dan homogenitas di atas, diperoleh hasil bahwa data tersebut normal dan homogen, karena data tersebut normal dan homogen, maka kita bisa melanjutkan untuk uji hipotesis data.

\section{HASIL DAN PEMBAHASAN}

Penelitian ini membuktikan bahwa secara simultan "terdapat pengaruh antara disiplin dan aktivitas belajar terhadap hasil belajar mahasiswa" yang dilihat dari nilai 
sig $0,005<0,05$, sedangkan secara parsial hanya disiplin yang memiliki pengaruh positif terhadap hasil belajar mahasiswa, yang dibuktikan dengan nilai sig 0,02< 0,05 . Sedangkan untuk variabel aktivitas belajar tidak berpengaruh terhadap hasil belajar mahasiswa dengan nilai sig 0,228 > 0,05 .

Penelitian ini juga membuktikan bahwa secara simultan disiplin dan aktivitas belajar mahasiswa mempunyai hubungan yang signifikan dengan hasil belajar mahasiswa PGMI yang dari diperoleh nilai Sig. F Change sebesar $0,005<0,05$, dan terdapat hubungan yang signifkan disiplin dengan hasil belajar siswa dilihat dari nilai sig alfha adalah $0,001<0,05$, namun aktivitas belajar tidak berhubungan dengan hasil belajar siswa yang dibuktikan dengan nilai sig sebesar 0,136> sig alfha 0,05 .

Berdasarkan hasil pengolahan data, diperoleh gambaran untuk disiplin berada pada klasifikasi “disiplin”, untuk gambaran aktivitas belajar berada pada klasifikasi "kurang aktif" dan gambaran hasil belajar mahasiswa PGMI berada pada klasifikasi "sedang".

Semakin aktif mahasiswa dalam mengikuti pembelajaran maka semakin banyak pengetahuan yang di dapat oleh mahasiswa, dan itu akan mengasah keberanian dan kemampuan siswa dalam mengemukakan pendapat, sehingga hasil belajarnya pun akan semakin bagus.

Namun, berdasarkan hasil penelitian ini aktivitas yang dilakukan mahasiswa tidak berpengaruh terhadap hasil belajar yang dilihat dari klasifikasi kurang aktif ternyata hanya $8,23 \%$ orang mahasiswa yang sangat aktif dan $25,89 \%$ orang yang aktif. Apabila digabungkan hanya 34,06\% mahasiswa yang aktif dalam proses pembelajaran.

Aktivitas belajar mahasiswa tidak berpengaruh diduga karena setelah mengisi pernyataan angket disiplin sebanyak 23 pernyataan, mahasiswa merasa jenuh untuk mengisi pernyatan angket tentang aktivitas belajar yang berjumlah 24 soal.

Tujuan disiplin adalah 1) Menolong anak menjadi matang pribadinya dan berubah dari sifat ketergantungan ke arah tidak ketergantungan, 2) Mencegah timbulnya persoalan-persoalan disiplin dan menciptakan situasi dan kondisi dalam belajar mengajar agar mengikuti segala peraturan yang ada dengan penuh perhatian'. Dari pendapat Sahertian dapat di ambil kesimpulan bahwa ketika tujuan disiplin sudah tercapai dengan baik, maka siswa akan menjadi mandiri dan teratur dalam kehidupan dan dalam belajarnya sehingga hasil belajarnyapun akan semakin tinggi (Tohari, 2018).

Berdasarkan hasil penelitian di atas, kedisiplinan mahasiswa tergolong kepada 
klasifikasi disiplin. Apabila dilihat dari distribusi disiplin, mahasiswa yang memiliki sikap disiplin. "Hasil belajar siswa pada hakikatnya adalah perubahan tingkah laku siswa setelah melewati proses pembelajaran. Tingkah laku sebagai hasil belajar dalam pengertian yang luas mencakup bidang kognitif, afektif dan psikomotorik" (Sudjana, 2020). Sedangkan hasil belajar adalah kemampuankemampuan yang dimiliki siswa sebagai akibat perbuatan belajar dan dapat diamati melalui penampilan siswa (learner's performance) (Nurdini, 2018).

Jadi dapat disimpulkan bahwa hasil belajar adalah sesuatu yang diperoleh mahasiswa setelah mahasiswa melakukan proses belajar dengan perubahan pada aspek kognitif, afektif, psikomotorik yang diwujudkan dalam bentuk skor atau angka setelah mengikuti tes hasil belajar. Hasil belajar merupakan hasil yang telah dicapai setelah dilaksanakan program kegiatan pembelajaran di kelas. Hasil belajar dalam periode tertentu dapat dilihat dari nilai akhir yang secara nyata dapat dilihat dalam bentuk angka-angka (Syahputra, 2017).

Dari penjabaran di atas, dapat disimpulkan bahwa sikap disiplin mahasiswa memiliki pengaruh yang positif terhadap hasil belajar mahasiswa. Apabila mahasiswa memiliki sikap yang kurang disiplin maka akan berpengaruh terhadap hasil belajar mahasiswa(Nurfitriyani, 2015). Aktivitas belajar mahasiswa juga memiliki pengaruh terhadap hasil belajar mahasiswa, semakin disiplin dan semakin aktif mahasiswa dalam belajar maka hasil belajarnyapun akan semakin bagus.

\section{KESIMPULAN}

Gambaran disiplin mahasiswa PGMI tergolong pada klasifikasi disiplin. Gambaran aktivitas belajar mahasiswa PGMI tergolong pada klasifikasi kurang aktif. Gambaran hasil belajar mahasiswa PGMI tergolong pada klasifikasi sedang. Terdapat pengaruh yang positif disiplin terhadap hasil belajar mahasiswa PGMI Tidak terdapat pengaruh aktivitas belajar terhadap hasil belajar mahasiswa PGMI. Secara bersama-sama terdapat pengaruh antara disiplin dan aktivitas belajar terhadap hasil belajar mahasiswa PGMI

\section{REFERENSI}

Darsiah, D. (2020). Pembinaan Kedisiplinan Peserta Didik Di Madrasah Aliyah Negeri 1 Merangin. Jurnal AlMujaddid Humaniora, 6(1), 26-32.

Ekawati, S. (2016). Pengaruh Kedisiplinan dan Aktivitas Belajar terhadap Hasil Belajar Matematika Siswa. Pedagogy: Jurnal Pendidikan Matematika, 1(2).

Herawati, N. I. (2016). Pendidikan Inklusif. EduHumaniora| Jurnal Pendidikan Dasar Kampus Cibiru, 2(1).

Nurdini, N. (2018). Pengaruh Disiplin Dan Aktivitas Belajar Terhadap Hasil Belajar Siswa Kelas V Madrasah Ibtidaiyah Negeri 1 Kota Padang Tahun Ajaran 2017/2018. 
Nurfitriyani, M. (2015). Pengaruh kreativitas dan kedisiplinan mahasiswa terhadap hasil belajar kalkulus. Formatif: Jurnal Ilmiah Pendidikan MIPA, 4(3).

Septiana, V. W., \& Mahmud, M. (2019). Pengaruh Disiplin Dan Aktivitas Belajar Terhadap Hasil Belajar Peserta Didik Di Min 1 Kota PadanG. Tarbiyah Al-Awlad, 9(2), 163-177.

Sudjana, N. (2020). Penelitian dan penilaian pendidikan. Sinar Baru Algensindo.

Sugiyono, M., \& Kuantitatif, P. (2009). Kualitatif, dan R\&D, Bandung: Alfabeta. Cet. VII.

Syahputra, D. (2017). Pengaruh kemandirian belajar dan bimbingan belajar terhadap kemampuan memahami jurnal penyesuaian pada siswa SMA Melati Perbaungan. ATTAWASSUTH: Jurnal Ekonomi Islam, 2(2), 368-388.

Tohari, S. (2018). Komitmen Kepala Sekolah dalam Membudayakan Disiplin Kerja Guru di SMP Negeri 1 Toili Kabupaten Banggai. Linear: Jurnal Ilmu Pendidikan, 2(1). 